\title{
Perancangan Enterprise Architecture Sistem Informasi E-Commerce Pada Toko Wingko \& Bandeng Presto Super Vit Menggunakan Zachman Framework
}

\author{
Indra Gamayanto ${ }^{1}$, Fenny Angelina ${ }^{2}$, Sasono wibowo ${ }^{3}$ \\ Fakultas Ilmu Komputer, Universitas Dian Nuswantoro \\ Jl Imam Bonjol 207 Semarang \\ e-mail: 1indra.gamayanto@dsn.dinus.ac.id, ${ }^{2} 112201405167 @$ mhs.dinus.ac.id, \\ ${ }^{3}$ sasono_skd@yahoo.com
}

Diterima: 29 Oktober 2019; Direvisi: 24 April 2020; Disetujui: 6 Mei 2020

\begin{abstract}
Abstrak
Toko Wingko \& Bandeng Presto Super Vit merupakan salah satu pusat oleh-oleh yang menjual makanan khas Semarang yaitu Bandeng Duri Lunak dan Wingko Babat. Timbulnya beragam permasalahan dan kendala yang dihadapi toko ini terutama dalam hal memasarkan produkproduknya yang masih bersifat konvensional yaitu dilakukan secara mouth-to-mouth, mengandalkan toko offline, dan menggunakan sistem konsinyasi ke toko-toko yang ada di Bandara, semarang. Hal ini disebabkan oleh karena rendahnya pemahaman mengenai pentingnya internet dalam peningkatan usaha serta terbatasnya pengetahuan mengenai jaringan pemasaran, adapun Zachman framework ini memiliki details proses dan mampu menghasilkan analisis yang lebih mendalam dibandingkan metode lainnya. Dari beberapa permasalahan yang timbul jika tidak segera ditangani maka dampaknya bisa membuat perkembangan bisnis menjadi terancam, salah satunya adalah toko akan mengalami penurunan volume penjualan. Oleh sebab itu dilakukannya penelitian ini dengan tujuan menciptakan model blueprint rancangan enterprise architecture system menggunakan metode Zachman Framework dengan menganalisis proses bisnis yang ada saat ini di Toko Wingko \& Bandeng Presto Super Vit untuk menghasilkan rancangan sistem yang dibutuhkan. Dari hasil analisis menggunakan Zachman Framework, Toko Wingko \& Bandeng Presto Super Vit membutuhkan sistem informasi e-commerce sebagai solusi pemecahan masalah pemasaran dan penjualan produk yang masih tergolong konvensional. Hasil dari penelitian ini adalah blueprint rancangan enterprise architecture system dan prototype sistem informasi e-commerce Toko Wingko \& Bandeng Presto Super Vit. Oleh sebab itu, ecommerce merupakan cara untuk memperluas market konsumen dan merupakan penggunaan tekcnologi informasi yang sangat diperlukan
\end{abstract}

Kata kunci: arsitektur enterprise, metode zachman framework, sistem informasie, e-commerce, blueprint

\begin{abstract}
Presto Super Vit's Wingko \& Milkfish Shop is one of the souvenir shops selling Semarang specialty food, namely Deng Soft Milkfish and Wingko Babat. The emergence of various problems and obstacles faced by this store, especially in terms of marketing products that are still conventional in nature that is done by mouth-to-mouth, relying on offline stores, and using a consignment system to shops in the airport, Semarang. This is due to the low understanding of the importance of the internet in increasing business and the limited knowledge of network marketing, while the Zachman framework has process details and is able to produce more indepth analysis compared to other methods. Of the several problems that arise if not addressed immediately, the impact can make business development become threatened, one of which is the
\end{abstract}


store will experience a decrease in sales volume. Furthermore, this research was conducted with the aim of creating a blueprint model of the enterprise architecture system design using the Zachman Framework method by analyzing the existing business processes at the Wingko \& Bandeng Presto Super Vit Store to produce the system designs needed. From the results of the analysis using the Zachman Framework, the Wingko \& Bandeng Presto Super Vit store requires an e-commerce information system as a solution to solving marketing problems and selling products that are still relatively conventional. The results of this study are the blueprint of the enterprise architecture system design and the prototype of the e-commerce information system Toko Wingko \& Bandeng Presto Super Vit. Therefore, e-commerce is a way to expand the consumer market and is the use of information technology that is needed

Keywords: enterprise architecture, zachman framework method, e-commerce information system, blueprint

\section{PENDAHULUAN}

Toko Wingko \& Bandeng Presto Super Vit merupakan salah satu pusat oleh-oleh yang menjual makanan khas Semarang yaitu Bandeng Duri Lunak dan Wingko Babat. Toko ini telah berkecimpung dalam bidang industri makanan selama 15 tahun dan masih menggunakan proses bisnis konvensional terutama dalam hal memasarkan produk-produknya yang masih dilakukan secara mouth-to-mouth, mengandalkan toko offline dan menggunakan sistem pemasaran titip jual (konsinyasi) ke toko-toko yang ada di Bandara Ahmad Yani Semarang.

Rendahnya pemahaman mengenai pentingnya internet dalam peningkatan usaha serta terbatasnya pengetahuan mengenai jaringan pemasaran menjadi penyebab utama Toko Wingko \& Bandeng Presto Super Vit kurang mampu bersaing secara global. Selain masalah tersebut, Toko Wingko \& Bandeng Presto Super Vit juga memiliki kendala dalam memberikan informasi yang jelas kepada para pelanggan maupun calon pelanggannya terkait dengan barang yang dijual, seperti informasi ketersediaan barang, informasi harga barang, dan informasi-informasi penting lainnya. Hal ini disebabkan karena Toko Wingko \& Bandeng Presto Super Vit belum memiliki media interaksi yang dapat berhubungan langsung dengan pelanggan secara online. Dari beberapa permasalahan yang timbul jika tidak segera ditangani maka akan berdampak buruk pada perkembangan Toko Wingko \& Bandeng Presto Super Vit, dimana toko akan mengalami penurunan penjualan dan para pelanggan lama kelamaan akan beralih untuk berbelanja ke toko lain yang menjual produk yang sama persis dengan cara yang lebih mudah, efektif, dan memberikan kenyamanan bagi mereka. Oleh sebab itu dilakukannya penelitian ini dengan tujuan menciptakan model blueprint rancangan enterprise architecture system untuk menghasilkan rancangan sistem yang dibutuhkan oleh Toko Wingko \& Bandeng Presto Super Vit.

Dalam penelitian ini penulis memanfaatkan kerangka kerja Zachman sebagai metode analisis atau thinking tool untuk merancang suatu enterprise architecture dengan memetakan kebutuhan data, proses, serta teknologi ke dalam setiap sel yang berjumlah 36 sel. Dari hasil analisis tersebut, ditemukan bahwa Toko Wingko \& Bandeng Presto Super Vit memerlukan suatu sistem informasi penjualan berbasis web atau e-commerce seperti pada [1] sebagai acuan untuk membantu menyelesaikan masalah-masalah yang terjadi pada Toko Wingko \& Bandeng Presto Super Vit supaya dapat memenangkan persaingan bisnis yang semakin ketat dalam era globalisasi saat ini

\section{METODE PENELITIAN}

Pada metode penelitian ini, terdapat beberapa tahapan yang akan dilakukan seperti disajikan pada gambar 1. Pada tahap awal dilakukan survey dan membuat questioners guna mengetahui faktor-faktor internal dan eksternal yang terdapat dan terjadi di dalam perusahaan, 
berikutnya adalah tahap analisis, metode analisis yang digunakan pada penelitian ini yaitu menggunakan Zachman Framework, yang merupakan suatu alat bantu berbentuk matrik dua dimensi terdiri atas 6 sel baris dan 6 sel kolom, yang dikembangkan untuk memotret arsitektur organisasi dari berbagai perspektif dan aspek, sehingga menghasilkan sebuah gambaran organisasi secara utuh. Karena terdiri dari 6 sel baris dan 6 sel[2];[3];[4];[5] kolom, maka kerangka kerja Zachman akan menghasilkan 36 sel, dimana setiap sel atau aspek pada matrik merupakan persimpangan antara perspektif dan fokusnya yang menyajikan aspek yang perlu digali dan diidentifikasi sesuai dengan kolom yang terkait.

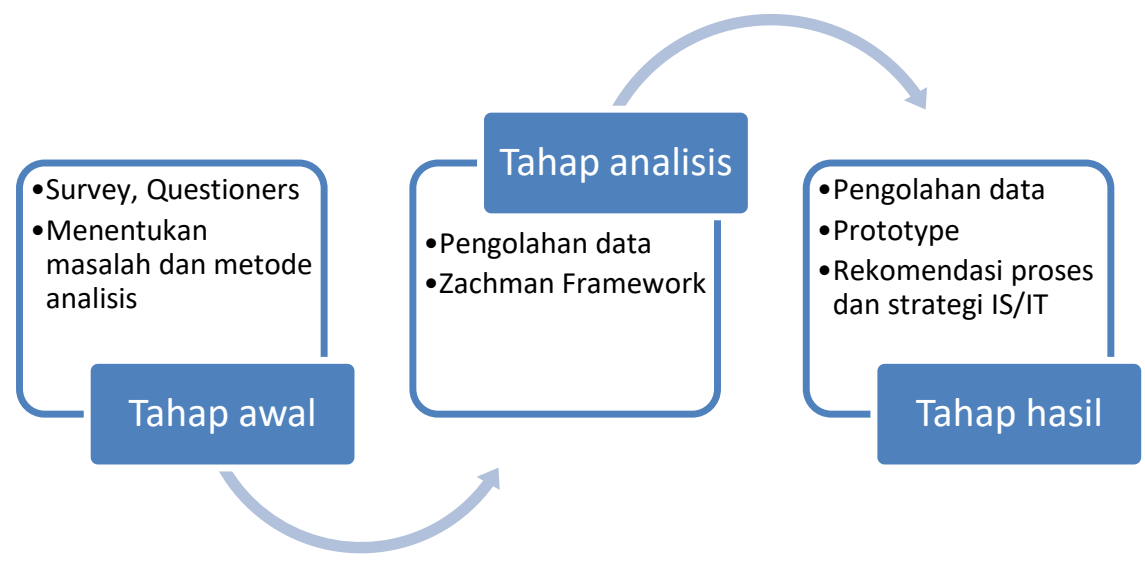

Gambar 1. Proses Penelitian

Dalam penelitian ini perspektif yang dijabarkan terdiri dari Planner (Scope), Owner (Business Model), Designer (System Model), Builder (Technology Model), Subcontractor (Detailed Representation) dan Functioning Enterprise dengan masing-masing kolom yang terdiri dari What, How, Where, Who, When, dan Why, sehingga diperoleh analisis yang dapat dilihat pada matrik Zachman $6 x 6$ berikut[6];[7];[8];[9] seperti tertuang pada gambar 1.

\begin{tabular}{|c|c|c|c|c|c|c|}
\hline & WMat & How & MHERE & พหо & wher & whr \\
\hline $\begin{array}{l}\text { Scope } \\
\text { covitoxis } \\
\text { Peespektif Planner }\end{array}$ & $\begin{array}{l}\text { Data-data penting } \\
\text { Toko WBPSV }\end{array}$ & $\begin{array}{l}\text { Daftar proses } \\
\text { bisnis utama di } \\
\text { Toko WBPSV }\end{array}$ & $\begin{array}{l}\text { Peta lokasi bisnis } \\
\text { Toko WBPSV }\end{array}$ & $\begin{array}{l}\text { Pihak-pihak } \\
\text { penting yang } \\
\text { terlibat dalam } \\
\text { proses bisnis }\end{array}$ & $\begin{array}{l}\text { Event penting } \\
\text { berkaitan dengan } \\
\text { proses bisnis }\end{array}$ & $\begin{array}{l}\text { Visi dan Misi } \\
\text { Toko WBPSV }\end{array}$ \\
\hline $\begin{array}{l}\text { GUSINESS } \\
\text { CONCEPIS } \\
\text { Perspektif Owner }\end{array}$ & $\begin{array}{c}\text { Rancangan } \\
\text { Use Case } \\
\text { System }\end{array}$ & $\begin{array}{l}\text { Skenario Use } \\
\text { Case }\end{array}$ & $\begin{array}{l}\text { Denah Gedung } \\
\text { Toko WBPSV }\end{array}$ & $\begin{array}{c}\text { SDM yang } \\
\text { terlibat untuk } \\
\text { membangun \& } \\
\text { mengelola sistem }\end{array}$ & $\begin{array}{l}\text { Time schedule } \\
\text { proyek } \\
\text { pembangunan } \\
\text { sistem }\end{array}$ & $\begin{array}{l}\text { Target/ujuan } \\
\text { pengadaan } \\
\text { sistem }\end{array}$ \\
\hline $\begin{array}{l}\text { SYSIEM } \\
\text { LOGIC } \\
\text { Penpektir Designer }\end{array}$ & $\begin{array}{c}\text { Rancangan Entity } \\
\text { Relationship } \\
\text { Diagram }\end{array}$ & $\begin{array}{l}\text { Rancangan } \\
\text { Sequence } \\
\text { Diagram }\end{array}$ & $\begin{array}{l}\text { Gambar desain } \\
\text { jaringan sistem }\end{array}$ & $\begin{array}{c}\text { Gambar desain } \\
\text { manual antarmuka } \\
\text { aplikasi }\end{array}$ & $\begin{array}{l}\text { Detail time } \\
\text { schedule } \\
\text { perancangan } \\
\text { model sistem }\end{array}$ & $\begin{array}{l}\text { Batasan/aturan } \\
\text { perancangan } \\
\text { model sistem }\end{array}$ \\
\hline $\begin{array}{l}\text { TECHNotoGy } \\
\text { Prrsics } \\
\text { Pernpektif Euilder }\end{array}$ & $\begin{array}{l}\text { Perancangan } \\
\text { database system } \\
\text { (Class Diagram }\end{array}$ & $\begin{array}{c}\text { Diagram alur } \\
\text { keseluruhan proses } \\
\text { fisik sistem }\end{array}$ & $\begin{array}{c}\text { Gambar desain } \\
\text { arsitektur } \\
\text { jaringan } \\
\text { teknologi }\end{array}$ & $\begin{array}{c}\text { Gambar } \\
\text { implementasi } \\
\text { antarmuka } \\
\text { aplikasi }\end{array}$ & $\begin{array}{l}\text { Detail time } \\
\text { schedule } \\
\text { perancangan } \\
\text { aplikasi }\end{array}$ & $\begin{array}{c}\text { Batasan/aturan } \\
\text { perancangan } \\
\text { desain aplikasi }\end{array}$ \\
\hline $\begin{array}{l}\text { Composent } \\
\text { ASsematils } \\
\text { Perspektif } \\
\text { Subeontractor }\end{array}$ & $\begin{array}{c}\text { Pembuatan } \\
\text { tabel-tabel } \\
\text { entitas }\end{array}$ & $\begin{array}{c}\text { Pembuatan } \\
\text { Activity Diagram }\end{array}$ & $\begin{array}{l}\text { Kebutuhan } \\
\text { infrastruktur } \\
\text { pendukung }\end{array}$ & $\begin{array}{l}\text { Konfigurasi hak } \\
\text { akses user pada } \\
\text { sistem }\end{array}$ & $\begin{array}{l}\text { Detail time } \\
\text { schedule proses } \\
\text { coding }\end{array}$ & $\begin{array}{l}\text { Aturan proses } \\
\text { pembuatan } \\
\text { program (coding) }\end{array}$ \\
\hline $\begin{array}{l}\text { OpERAntovs } \\
\text { CLAssts } \\
\text { Punctioning } \\
\text { Enterprise }\end{array}$ & $\begin{array}{l}\text { Pengisian data- } \\
\text { data atribut di } \\
\text { setiap tabel entitas }\end{array}$ & $\begin{array}{l}\text { Print out aplikasi } \\
\text { \& pengujian } \\
\text { black box }\end{array}$ & $\begin{array}{c}\text { Konfigurasi } \\
\text { kebutuhan } \\
\text { hardware \& } \\
\text { software }\end{array}$ & $\begin{array}{l}\text { Daftar user yang } \\
\text { menggunakan } \\
\text { sistem }\end{array}$ & $\begin{array}{l}\text { Time scbedule } \\
\text { keseluruhan } \\
\text { proyek sistem }\end{array}$ & $\begin{array}{c}\text { Petunjuk } \\
\text { penggunaan } \\
\text { fitur-fitur } \\
\text { dalam sistem }\end{array}$ \\
\hline
\end{tabular}

Gambar 2. Analisis Menggunakan Zachman Framework

Gambar 2 diatas merupakan hasil blueprint rancangan enterprise architecture system berbentuk 36 sel matrik Zachman yang digunakan sebagai acuan untuk merancang sistem 
informasi e-commerce yang akan dibangun di Toko Wingko \& Bandeng Presto Super Vit.

Pada tahap hasil, pengolahan data yang sudah sempurna, menghasilkan sebuah prototype website e-commerce untuk dapat membantu perusahaan dalam mengembangkan tokonya dan dapat mampu menghadapi globalisasi dan persaingan

\section{HASIL DAN PEMBAHASAN}

Berikut adalah hasil penjabaran tiap sel dari matrik 36 sel Zachman Framework:

\subsection{The Planner Perspective (Scope Context)}

Perspektif ini merupakan baris pertama dari Zachman framework yang mendefinisikan ruang lingkup bisnis enterprise secara global dilihat dari sudut pandang planner yang mencakup data-data utama, daftar proses bisnis, lokasi aktivitas bisnis, struktur organisasi, pendefinisian visi dan misi pada Toko Wingko \& Bandeng Presto Super Vit.

a) Kolom What $x$ Planner

Kolom ini berisikan daftar entitas atau data-data utama dalam bisnis yang ada pada Toko Wingko \& Bandeng Presto Super Vit terkait dengan sistem informasi yang akan dibangun. Datadata yang ada yaitu sebagai berikut: 1) Data dan Informasi Perusahaan, 2) Data Pelanggan, 3) Data Karyawan, 4) Data Produk, 5) Data Pemesanan, 6) Data Pembayaran, 7) Data Pengiriman

b) Kolom How x Planner

Pada kolom ini akan dijelaskan tentang proses utama yang menyangkut proses pemasaran dan penjualan produk di Toko Wingko \& Bandeng Presto Super Vit, dimana terdapat tiga proses bisnis diantaranya yaitu proses pemesanan dan penjualan langsung, proses pemesanan dan penjualan melalui telepon, dan proses pemasaran titip jual (konsinyasi).[10];[11];[12]

c) Kolom Where $x$ Planner

Kolom ini membahas mengenai lokasi bisnis utama tempat dimana Toko Wingko \& Bandeng Presto Super Vit beroperasi. Lokasi bisnis Toko Wingko \& Bandeng Presto Super Vit berada di Jalan Selomas Raya B-17 Semarang.

d) Kolom Who x Planner

Kolom ini memaparkan daftar sumber daya manusia atau pihak-pihak yang terlibat dan ikut berperan penting dalam menjalankan proses bisnis di Toko Wingko \& Bandeng Presto Super Vit, antara lain yaitu pimpinan, bagian pemasaran, bagian gudang, bagian Produksi dan kasir.

e) Kolom When x Planner

Sel ini menjelaskan tentang seluruh rangkaian kegiatan secara global yang berkaitan dengan proses pemasaran dan penjualan produk di Toko Wingko \& Bandeng Presto Super Vit.

f) Kolom Why x Planner

Visi dan misi dari Toko Wingko \& Bandeng Presto Super Vit, yaitu sebagai berikut :

1. Visi : Menjadi perusahaan terdepan yang unggul dalam menghasilkan sajian istimewa khas Semarang berkualitas baik dengan harga yang terjangkau, menyehatkan bagi rakyat Indonesia, dan berkomitmen untuk selalu melayani konsumen dengan sepenuh hati.

2. Misi : Meningkatkan kualitas dan terus berinovasi baik dalam produk maupun pelayanan, serta mengembangkan usaha di beberapa tempat yang strategis untuk memperkenalkan produk secara lebih luas ke masyarakat.

\subsection{The Owner Perspective (Business Model)}

Perspektif ini mendefinisikan model enterprise berupa gambaran sistem yang diusulkan menurut sudut pandang owner tentang bagaimana sistem yang akan dibangun tersebut akan berjalan, siapa saja orang-orang yang terlibat dalam kegiatan pembangunan sistem, bagaimana menyusun time schedule proyek, dan apa tujuan dibangunnya sebuah sistem[13];[14];[15] 


\section{a) Kolom What $x$ Owner}

Kolom ini berisi gambaran ringkas dari sistem informasi e-commerce yang menjelaskan bagaimana entitas-entitas yang ada pada kolom What x Planner saling berhubungan dengan sistem dalam menjalankan proses bisnis utama yang dimodelkan dengan Use Case Diagram seperti gambar 3.

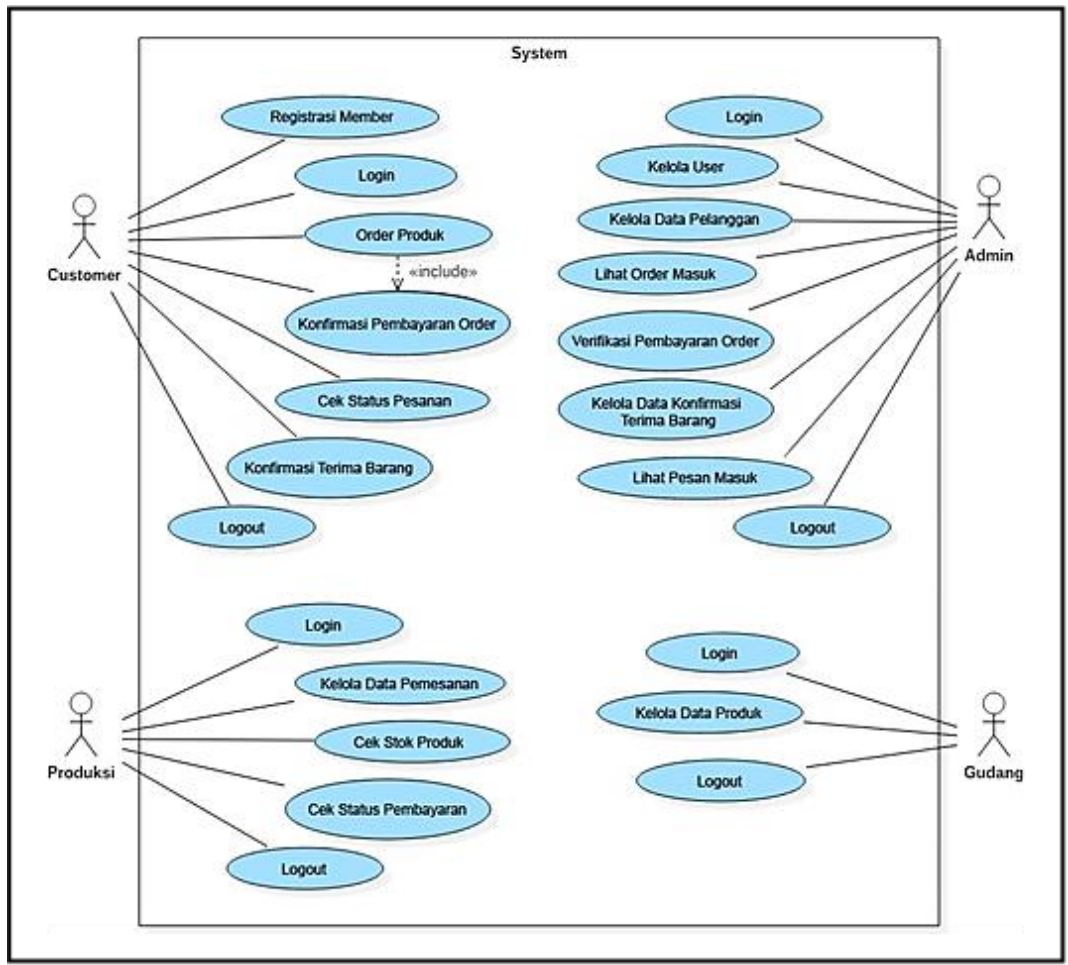

Gambar 3. Use Case Diagram Sistem Informasi E-Commerce

b) Kolom How x Owner

Pada kolom ini dibahas mengenai deskripsi use case yang telah digambarkan sebelumnya pada kolom what perspektif owner, sebagai penjelasan alur jalannya proses use case dari sisi masing-masing aktor dan sistem.

c) Kolom Where $x$ Owner

Sel ini menggambarkan lokasi operasional berupa denah gedung Toko Wingko \& Bandeng Presto Super Vit, dimana nantinya beberapa ruang akan digunakan untuk lokasi penempatan sistem informasi yang mendukung proses pemasaran dan penjualan produk secara online.

d) Kolom Who x Owner

Berisikan daftar sumber daya manusia yang ditugaskan owner atau pihak-pihak yang terlibat dalam menjalankan aktivitas perancangan, pembangunan dan pengelolaan sistem informasi e-commerce pada Toko Wingko \& Bandeng Presto Super Vit, orang-orang tersebut yaitu analis sistem, programmer web, desainer web dan grafis, operator, teknisi komputer dan jaringan, penanggung jawab proyek.

e) Kolom When $x$ Owner

Kolom ini berisikan jadwal kegiatan atau time schedule yang digunakan sebagai acuan pembangunan proyek sistem informasi e-commerce pada Toko Wingko \& Bandeng Presto Super Vit, dimana penelitian ini dilakukan pada bulan Maret 2018 sampai dengan bulan Juni 2018. Time schedule pembangunan proyek ditampilkan pada gambar 4. 


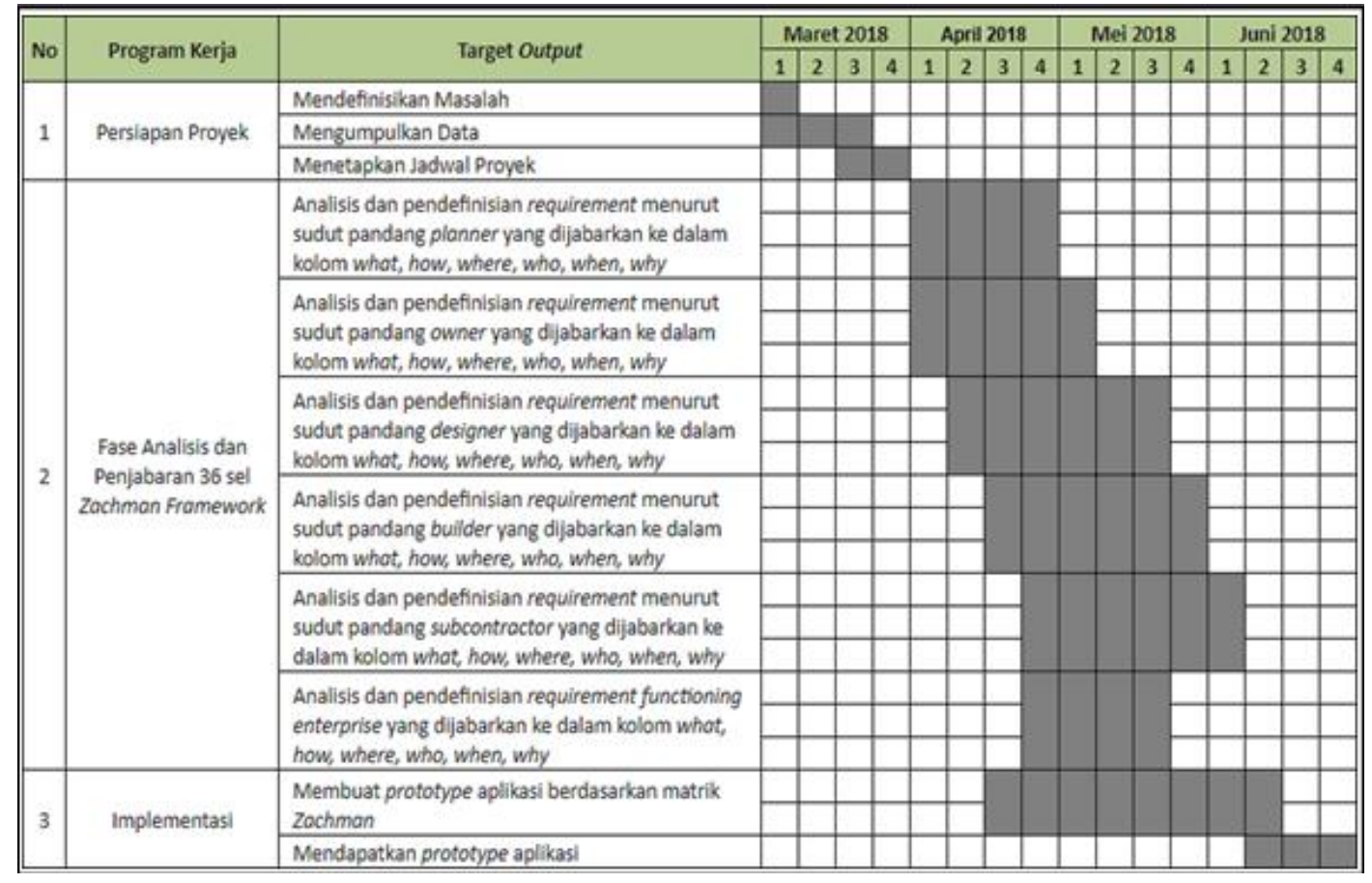

Gambar 4. Time Schedule Penelitian

\section{f) Kolom Why $x$ Owner}

Target atau tujuan-tujuan yang ingin dicapai Toko Wingko \& Bandeng Presto Super Vit terkait dengan perancangan dan pembangunan sistem informasi e-commerce ini adalah :

1. Sebagai sarana untuk memperluas pangsa pasar dan meningkatkan penjualan produk pada Toko Wingko \& Bandeng Presto Super Vit.

2. Memperbaiki manajemen proses bisnis yang lebih baik di Toko Wingko \& Bandeng Presto Super Vit untuk membantu meningkatkan efektivitas dan efisiensi dalam lingkungan kerja sehingga kinerja karyawan dapat lebih optimal dan kualitas layanan yang diberikan kepada konsumen menjadi lebih baik.

\subsection{The Designer Perspective (System Model)}

Pada perspektif ini digambarkan berbagai macam desain/model teknis perancangan seperti desain ERD, UML, desain peta jaringan usulan, desain manual interface, dan desain lainnya yang menjadi dasar pedoman implementasi sistem informasi e-commerce di Toko Wingko \& Bandeng Presto Super Vit.

a) Kolom What $x$ Designer

Kolom ini berisi model ERD yang menggambarkan struktur logis hubungan antar entitas dari suatu basis data yang ditunjukan pada gambar 5, yang didesain untuk membangun sistem informasi e-commerce pada Toko Wingko \& Bandeng Presto Super Vit.

b) Kolom How x Designer

Kolom how berisi rancangan jalannya proses sistem informasi e-commerce secara lebih detail yang dimodelkan dengan Sequence Diagram pada gambar 6.

c) Kolom Where $x$ Designer

Berikut adalah desain peta jaringan pada gambar 7 yang dirancang dan diusulkan oleh pihak designer untuk digunakan pada sistem informasi e-commerce yang sesuai dengan kebutuhan Toko Wingko \& Bandeng Presto Super Vit. 


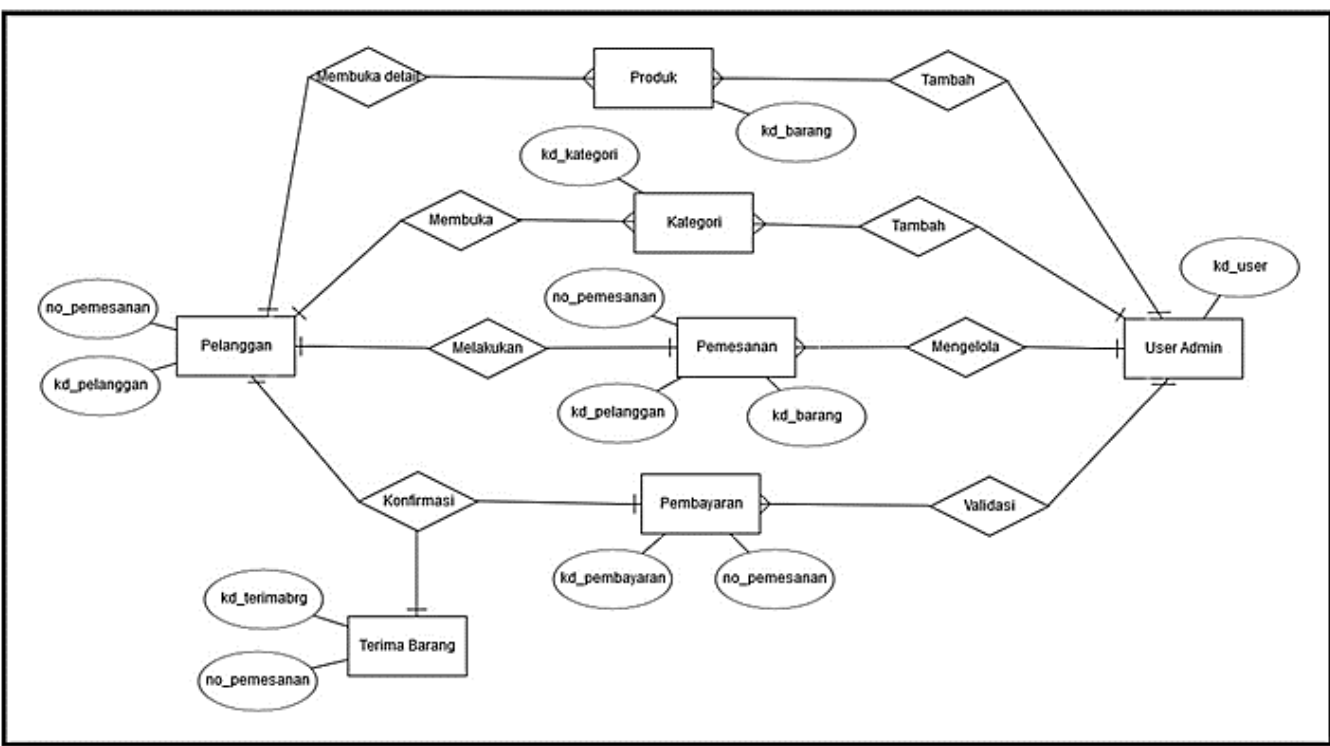

Gambar 5. Entity Relationship Diagram

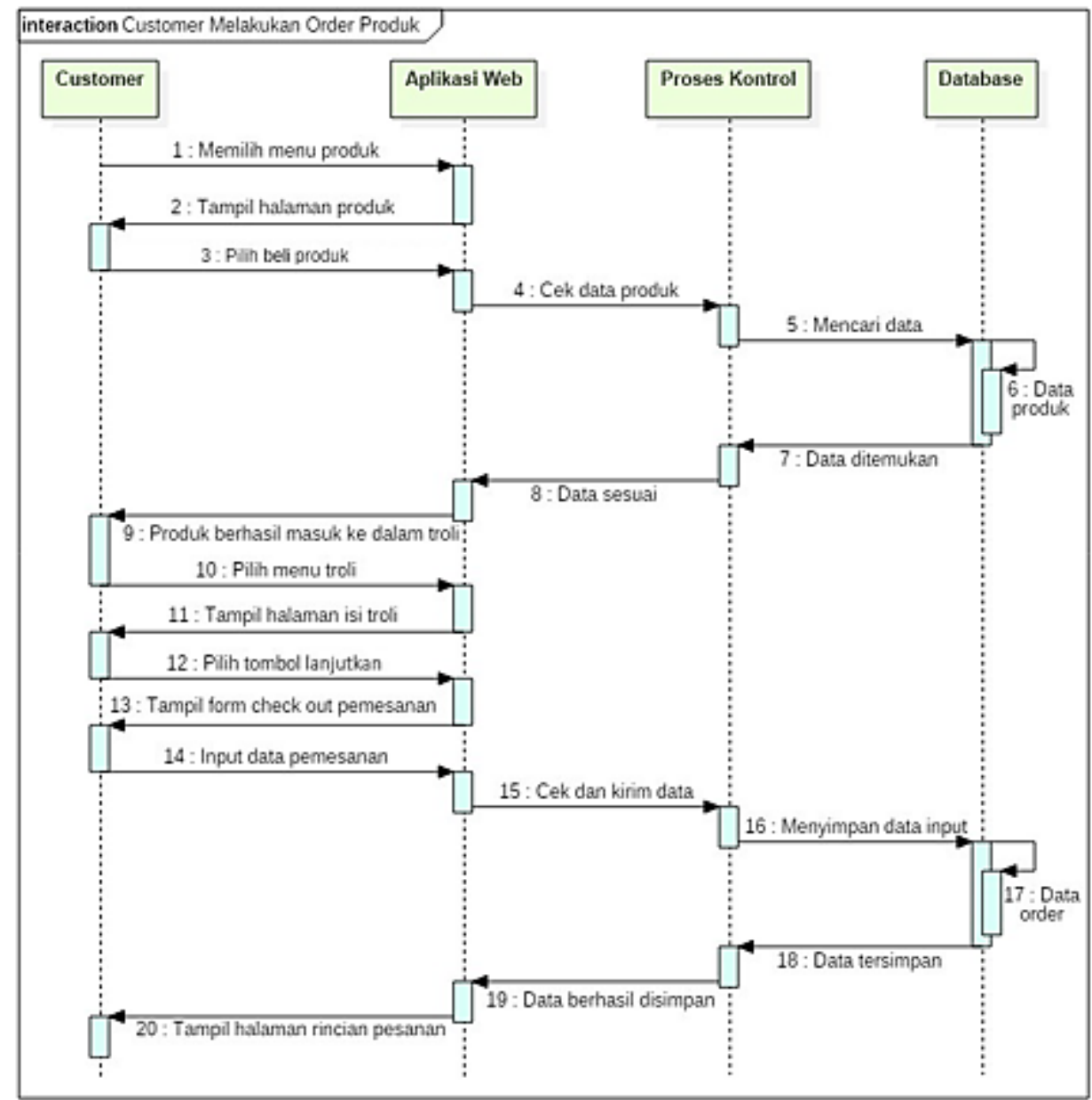

Gambar 6. Sequence Diagram Customer Melakukan Order Produk 


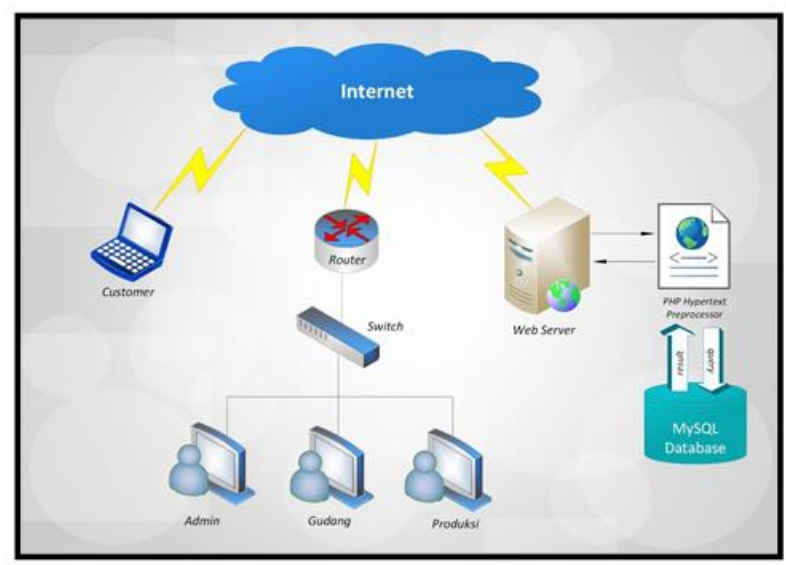

Gambar 7. Desain Jaringan Usulan

d) Kolom Who x Designer

Pada bagian ini berisikan desain manual antarmuka pengguna dan desain tampilan form input data dan tabel output dari sistem informasi Toko Wingko \& Bandeng Presto Super Vit yang tersaji pada gambar 8, dimana desain manual tersebut nantinya akan digunakan sebagai refrensi/acuan dalam membuat interface sistem yang sesungguhnya yang dapat berinteraksi dengan user.

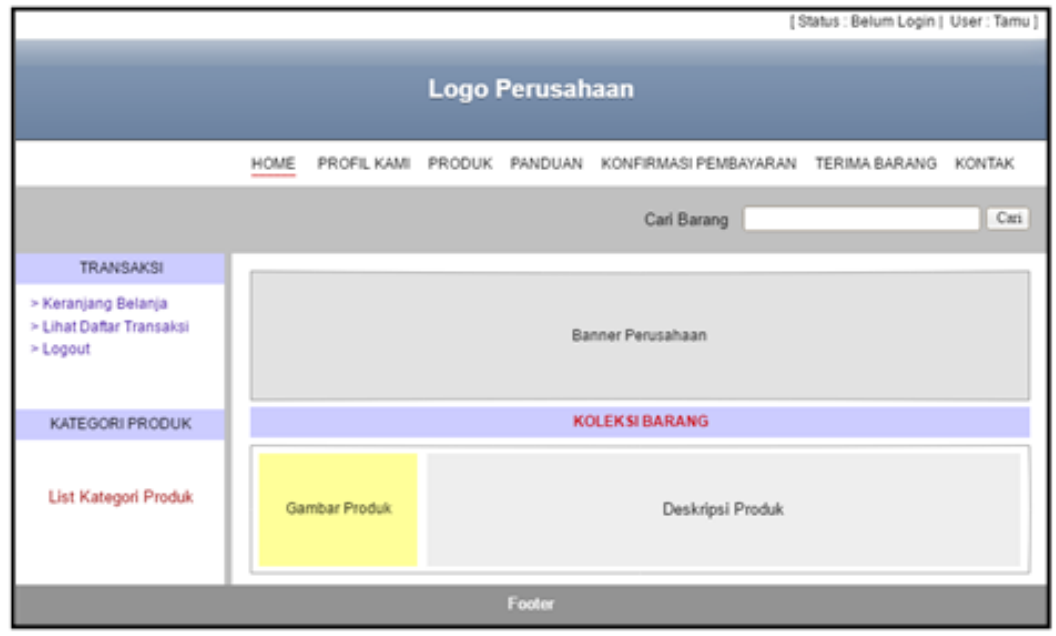

Gambar 8. Desain Manual Halaman Produk

e) Kolom When $x$ Designer

\begin{tabular}{|c|l|c|c|c|c|c|}
\hline \multirow{2}{*}{ No } & \multicolumn{5}{|c|}{ Rencana Kegiatan } & \multicolumn{5}{c|}{ April 2018 } & Mei 2018 \\
\cline { 3 - 7 } & & 1 & 2 & 3 & 4 & 1 \\
\hline 1 & Penentuan Entitas & & & & & \\
\hline 2 & Pembuatan Use Case Diagram dan Skenario Use Case & & & & & \\
\hline 3 & Perancangan Activity Diagram & & & & & \\
\hline 4 & Perancangan ER Diagram & & & & & \\
\hline 5 & Perancangan Sequence Diagram & & & & & \\
\hline 6 & Perancangan Class Diagram & & & & & \\
\hline 7 & Pembuatan Desain Manual Antarmuka Aplikasi & & & & & \\
\hline
\end{tabular}

Gambar 9. Time Schedule Detail Perancangan Model Sistem 
Dalam kolom ini akan dibahas time schedule detail rencana kegiatan yang diperlukan dalam perancangan model sistem informasi e-commerce pada Toko Wingko \& Bandeng Presto Super Vit menurut sudut pandang designer atau perancang model sistem. Pemodelan sistem dibuat pada bulan April 2018 sampai Mei 2018 yang divisualkan dalam bentuk GANTT chart.

f) Kolom Why $x$ Designer

kolom why perspektif designer ini akan dijelaskan mengenai batasan-batasan atau aturan yang diterapkan dalam proses perancangan model sistem informasi $e$-commerce Toko ingko \& Bandeng Presto Super Vit yang dirancang menggunakan pemodelan berbasis UML. Adapun beberapa batasan dan aturan yang diterapkan antara lain :

1. Desain interface halaman administrator dan customer dibuat berbeda. Antarmuka sistem untuk customer dikhususkan hanya untuk berbelanja, sedangkan antarmuka halaman back- end administrator dikhususkan untuk mengelola website tersebut.

2. Aplikasi e-commerce berbasiskan web ini berisi fitur-fitur yang dapat diakses oleh customer seperti Register Online, Login, Profil Perusahaan, Panduan Belanja, Kategori Produk, dan harus bisa melakukan transaksi jual beli secara online dengan dilengkapi form pemesanan, form konfirmasi pembayaran, halaman cek pesanan dan form konfirmasi penerimaan barang[16]

\subsection{The Builder Perspective (Technology Model)}

Sudut pandang builder menjelaskan tentang bagaimana model fisik teknologi dapat digunakan untuk pembangunan arsitektur sistem informasi e-commerce di Toko Wingko \& Bandeng Presto Super Vit berdasarkan model rancangan yang telah ditetapkan.

\section{a) Kolom What $x$ Builder}

Kolom ini berisikan perancangan database sistem informasi e-commerce Toko Wingko \& Bandeng Presto Super Vit yang dimodelkan dengan Class Diagram beserta atribut dan operasinya.

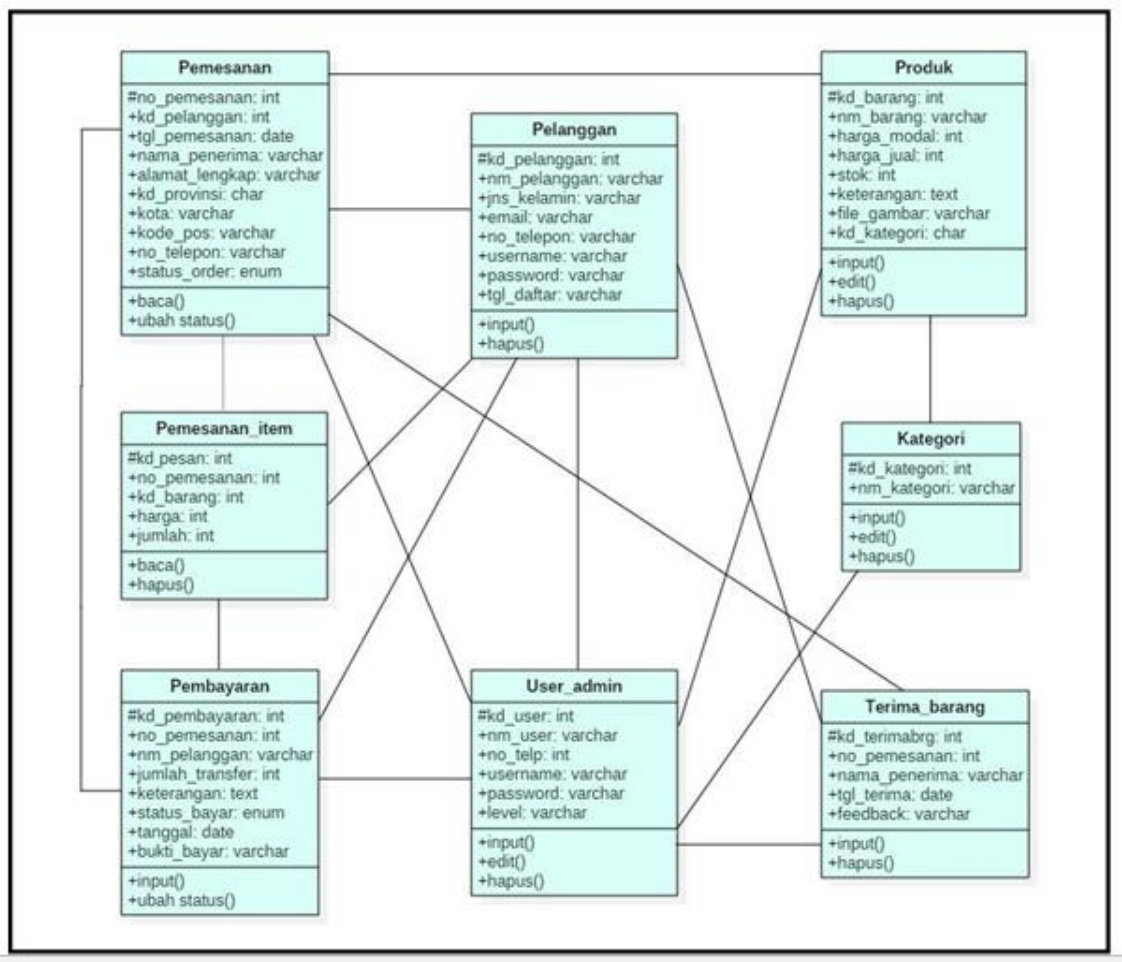

Gambar 10. Class Diagram 


\section{b) Kolom How x Builder}

Kolom ini membahas mengenai diagram alur keseluruhan proses fisik pada sistem informasi e-commerce Toko Wingko \& Bandeng Presto Super Vit yang dimodelkan dengan alat bantu visual Rich Picture untuk membantu memahami proses bisnis secara keseluruhan.

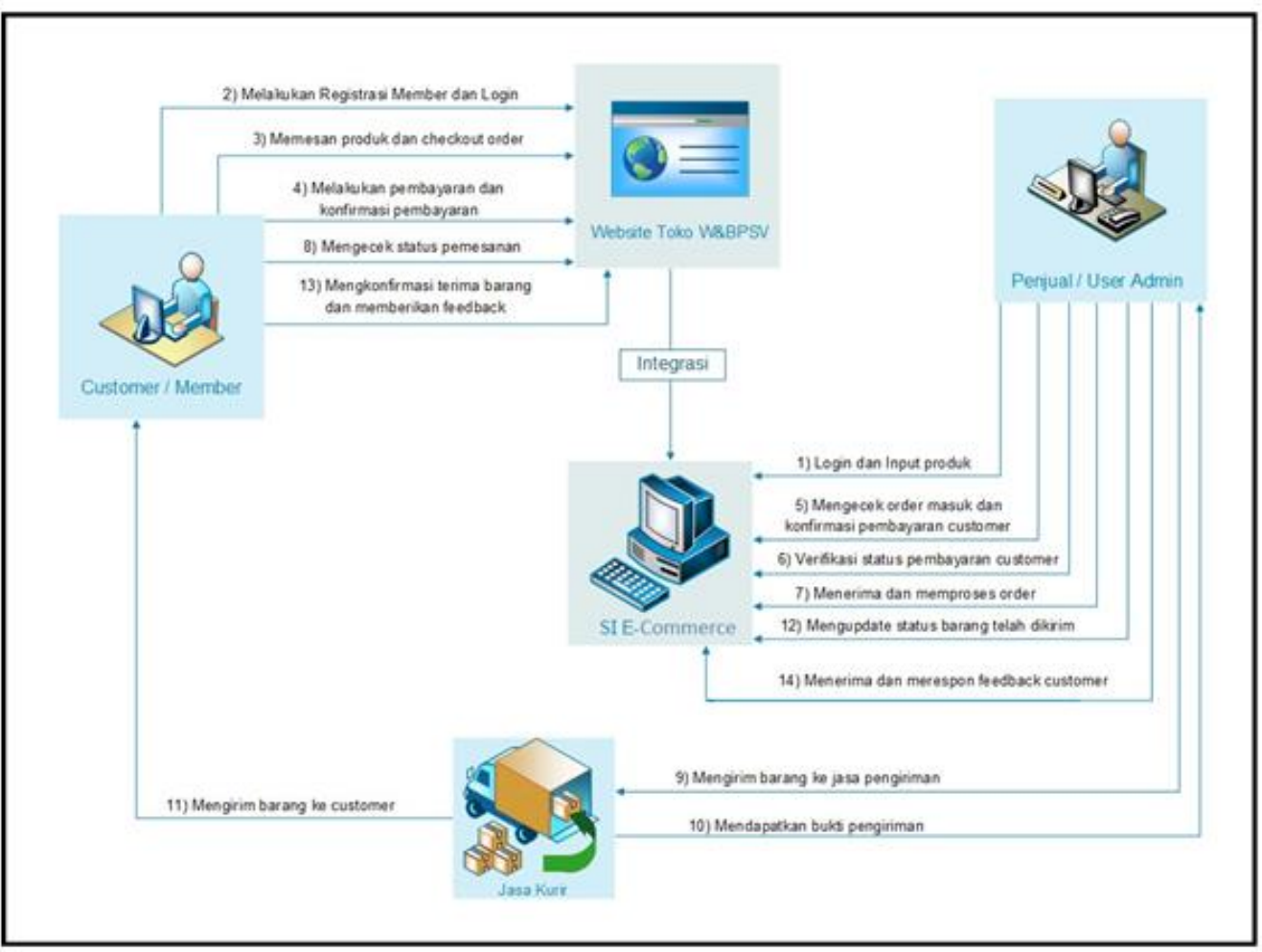

Gambar 11. Rich Picture Alur Proses Fisik Sistem Informasi

\section{c) Kolom Where $x$ Builder}

Kolom jaringan perspektif builder ini menghasilkan sel yang berisi arsitektur jaringan teknologi e-commerce sebagai berikut :

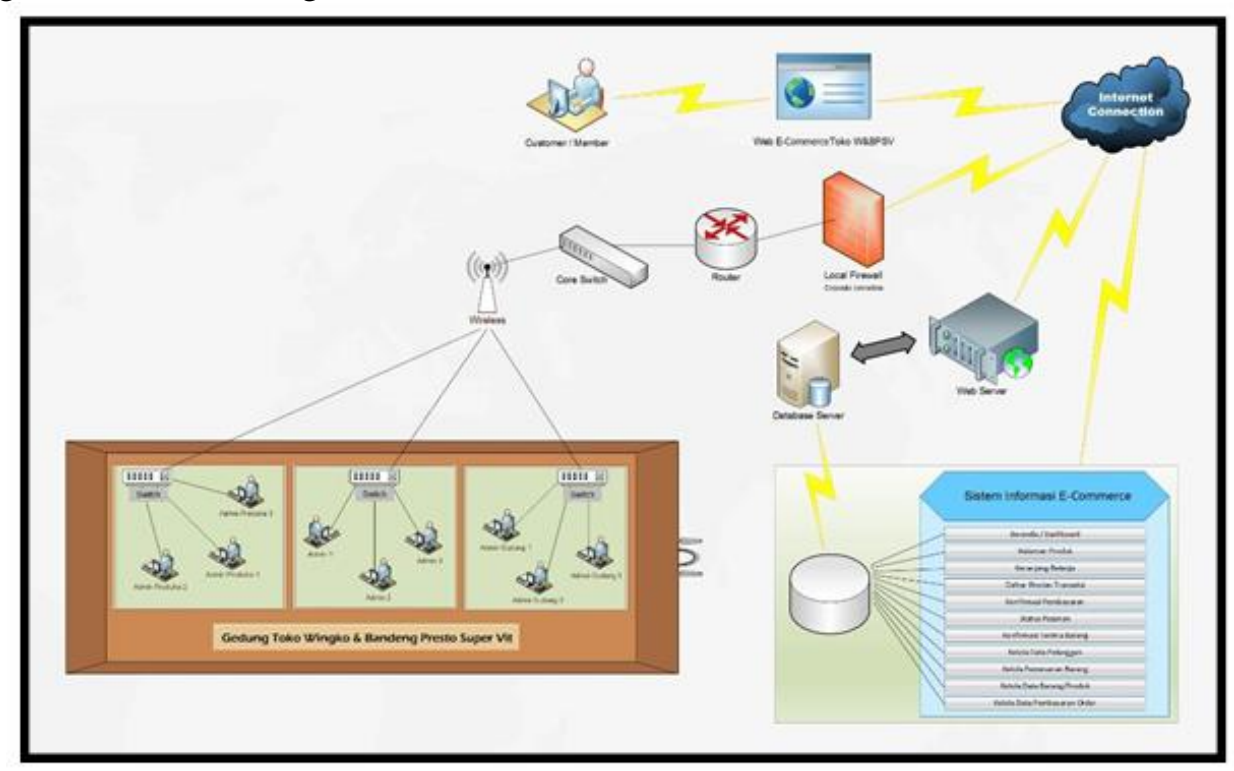

Gambar 12. Desain Arsitektur Jaringan Teknologi

d) Kolom Who x Builder 
Kolom ini berisikan gambar implementasi antarmuka website sistem informasi $e$ commerce toko Wingko \& Bandeng Presto Super Vit yang sebelumnya digambarkan dalam bentuk mock-up antarmuka sistem, kemudian diterapkan menjadi tampilan sesungguhnya dalam bentuk aplikasi berbasiskan website.

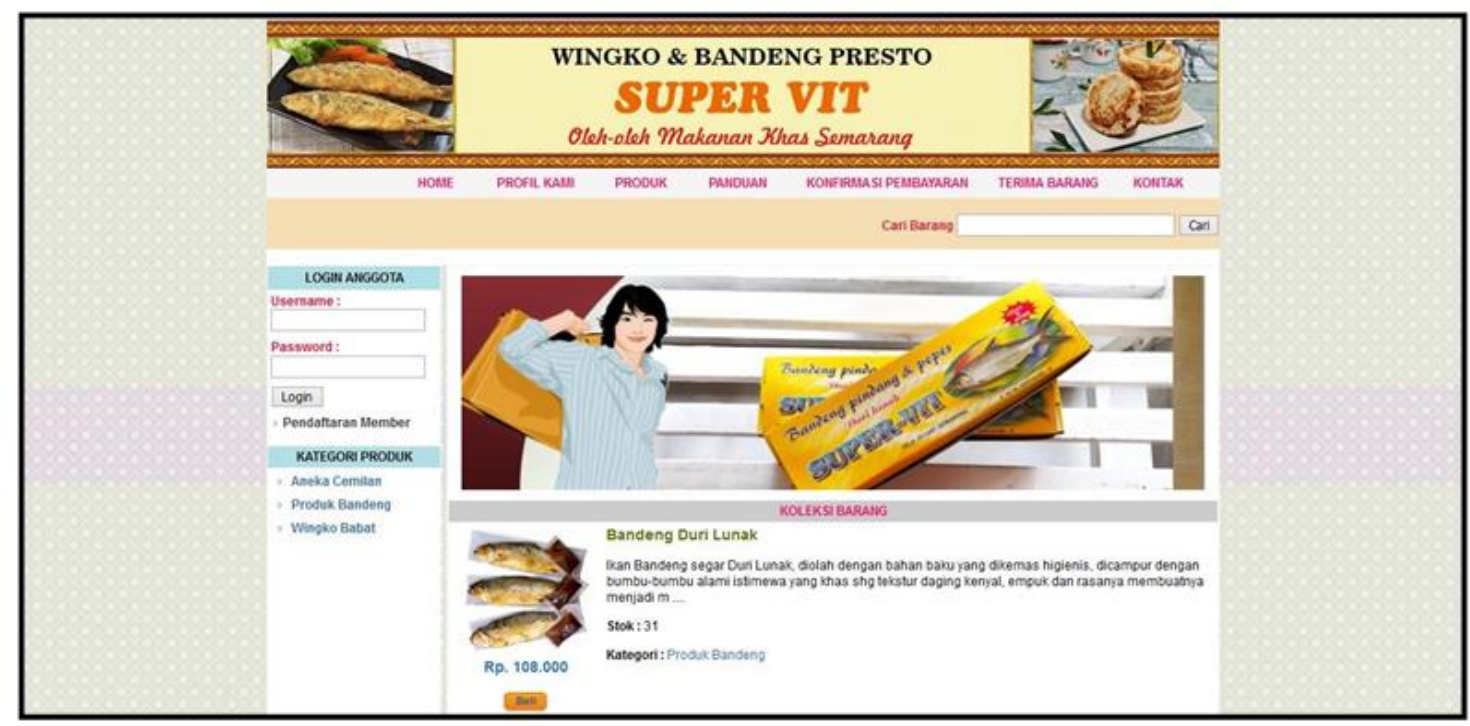

Gambar 13. Halaman Home Web E-Commerce

\section{e) Kolom When $x$ Builder}

Pada kolom ini dijelaskan detail jadwal perancangan aplikasi berupa website sistem informasi e-commerce yang dibuat sesuai dengan kebutuhan Toko Wingko \& Bandeng Presto Super Vit dalam bentuk GANTT chart, kemudian akan didelegasikan ke tim yang akan melaksanakan proyek.

\begin{tabular}{||c|c|c|c|c|c|}
\hline \multirow{2}{*}{ No } & Rencana Kegiatan & April 2018 & \multicolumn{3}{|c|}{ Mei 2018 } \\
\cline { 3 - 6 } & & $\mathbf{4}$ & $\mathbf{1}$ & $\mathbf{2}$ & $\mathbf{3}$ \\
\hline 1 & Pembuatan Database & & & & \\
\hline \multirow{2}{*}{2} & $\begin{array}{l}\text { Penerapan Desain Antarmuka User dan } \\
\text { Desain Input-Output Data Pada Sistem }\end{array}$ & & & & \\
\hline
\end{tabular}

Gambar 14. Time Schedule Perancangan Aplikasi

f) Kolom Why x Builder

Dalam kolom ini akan dijabarkan mengenai batasan-batasan atau aturan yang diterapkan dalam proses perancangan aplikasi web sistem informasi $e$-commerce, yaitu :

1. Sistem ini dibangun berbasis web menggunakan bahasa pemrograman PHP, HTML, Javascript, dan desain layout aplikasi menggunakan CSS.

2. Aplikasi yang digunakan sebagai tempat penyimpanan dan pengolahan data berbentuk database adalah MYSQL yang diolah menggunakan aplikasi PhpMyAdmin.

3. Untuk penelitian ini, aplikasi hanya dapat dijalankan pada jaringan localhost, yaitu dengan menggunakan web server Apache XAMPP dan browser Mozilla Firefox untuk menjalankan fungsi program tersebut.

\subsection{The Subcontractor Perspective (Detailed Representation)}


Perspektif subcontractor (detailed representation) berkaitan dengan model-model yang menggambarkan bagaimana komponen dirakit, dioperasikan dan dikonfigurasi oleh programmer ke dalam produk akhir dari berbagai elemen dalam sistem informasi $e$-commerce yang dibangun.

a) Kolom What $x$ Subcontractor

Kolom ini berisikan tabel-tabel entitas dalam suatu database yang dibuat dengan menggunakan PhpMyAdmin berdasarkan rancangan class diagram yang telah didefinisikan sebelumnya ada kolom what perspektif builder.

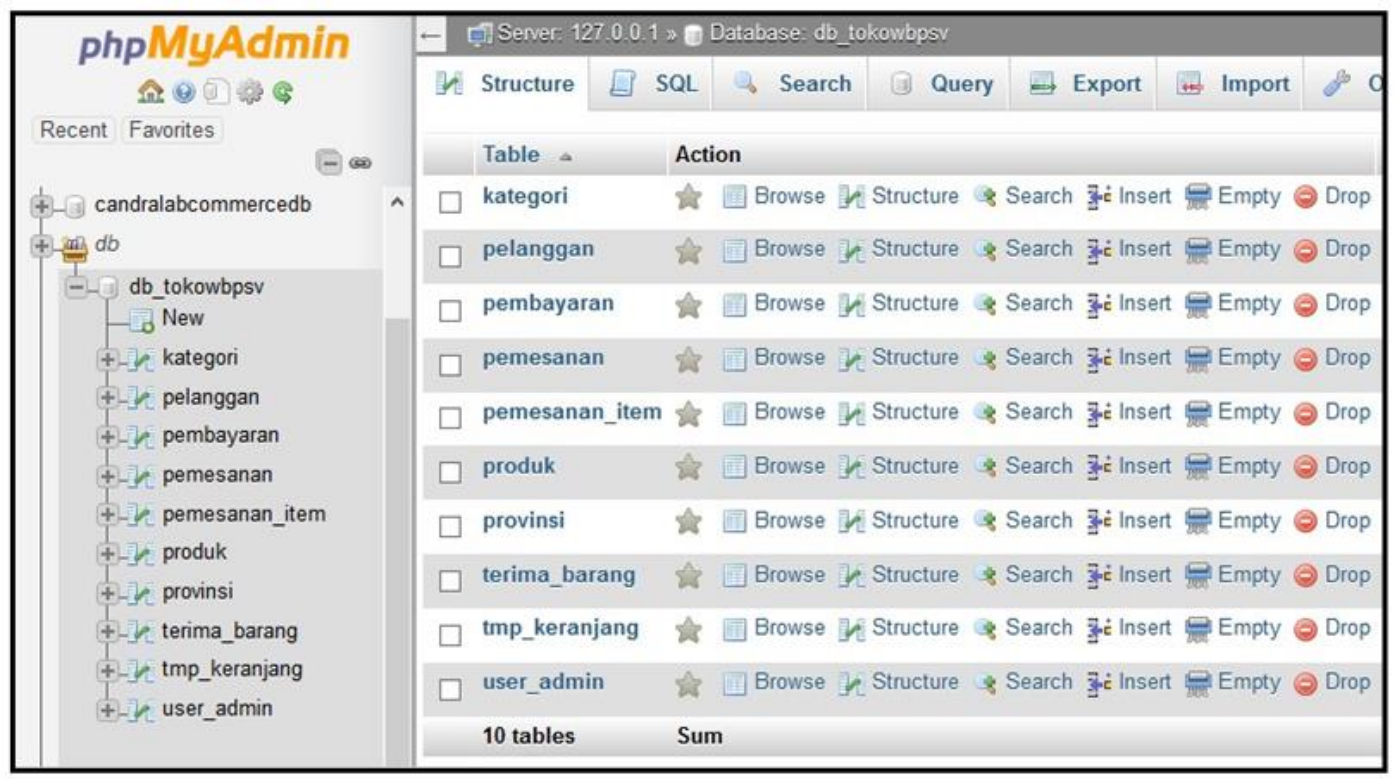

Gambar 15. Tabel Entitas Dalam Database

b) Kolom How $x$ Subcontractor

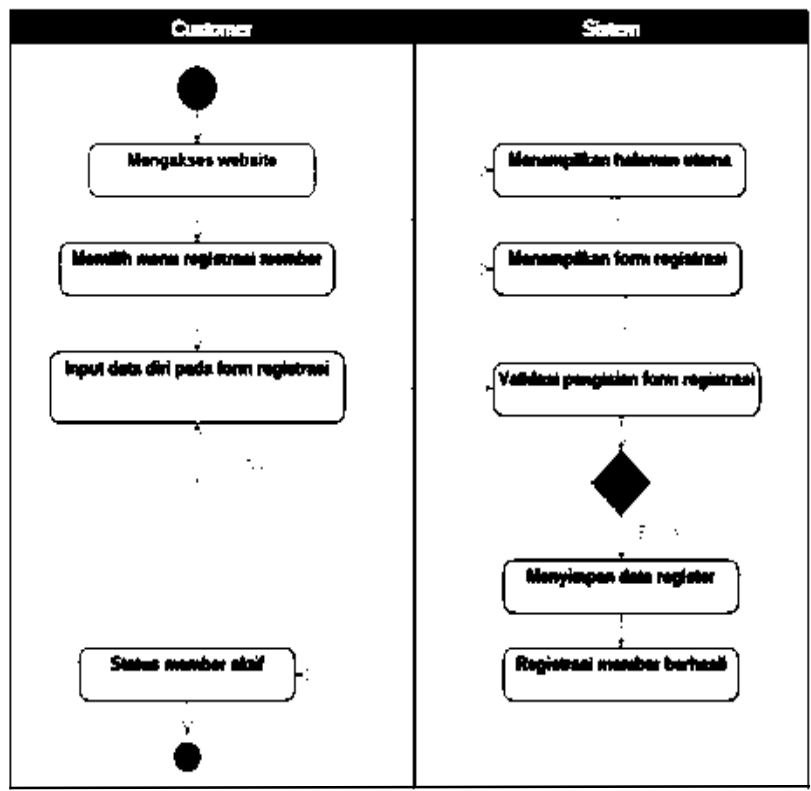

Gambar 16. Activity Diagram Order Produk 
Kolom how perspektif subcontractor ini berisikan detail penjelasan alur proses dalam sebuah sistem yang dimodelkan dalam bentuk activity diagram pada gambar 16.

c) Kolom Where $x$ Subcontractor

Pada bagian ini akan dibahas mengenai infrastruktur jaringan pendukung (perangkat fisik) yang dibutuhkan dalam melaksanakan penerapan sistem informasi e-commerce di Toko Wingko \& Bandeng Presto Super Vit, yaitu:

Tabel 1. Infrastruktur Jaringan Pendukung

\begin{tabular}{clll}
\hline No & Nama Device & Spesifikasi & Kategori \\
\hline 1. & Komputer Client & 1 GHz 32-bit & Perangkat Keras \\
2. & Router & D-Link [DSL-526E] & Perangkat Keras \\
3. & Switch & D-Link [DES-1008A] & Perangkat Keras \\
4. & Wi-Fi & Kecepatan 5 Mbps & Perangkat Keras \\
5. & Kabel Jaringan & UTP Verified CAT 5 & Perangkat Keras \\
6. & Konektor & RJ-45 & Perangkat Keras \\
\hline
\end{tabular}

d) Kolom Who x Subcontractor

Pada kolom ini pelaksana (subcontractor) mendefinisikan hak akses yang diberikan kepada masing-masing user dengan tingkat akses berbeda-beda disesuaikan dengan tanggung jawabnya masing-masing dalam menjalankan sistem informasi e-commerce di Toko Wingko \& Bandeng Presto Super Vit.

Tabel 2. User Level Akses Sistem Informasi

\begin{tabular}{|c|c|c|c|c|c|}
\hline \multirow[b]{2}{*}{ No } & \multirow[b]{2}{*}{ Kemampuan User } & \multicolumn{4}{|c|}{ Level User } \\
\hline & & Admin & Produksi & Gudang & Customer \\
\hline 1. & Pengaturan User Admin & $\checkmark$ & $x$ & $x$ & $x$ \\
\hline 2. & Kelola Data Pelanggan & $\boldsymbol{v}$ & $x$ & $x$ & $\mathrm{x}$ \\
\hline 3. & Upload, Edit, Hapus Produk & $\boldsymbol{v}$ & $x$ & $\boldsymbol{\gamma}$ & $x$ \\
\hline 4. & Lihat Data Order Masuk & $\boldsymbol{V}$ & $\boldsymbol{\gamma}$ & $\boldsymbol{V}$ & $\mathrm{x}$ \\
\hline 5. & Kelola Data Pemesanan & $\boldsymbol{\nu}$ & $\boldsymbol{V}$ & $x$ & $x$ \\
\hline 6. & Lihat Data Pembayaran & $\boldsymbol{v}$ & $\boldsymbol{v}$ & $x$ & $\mathrm{x}$ \\
\hline 7. & Kelola Data Pembayaran & $\boldsymbol{\nu}$ & $x$ & $\mathrm{x}$ & $x$ \\
\hline 8. & Kelola Data Penerimaan Barang & $\boldsymbol{\nu}$ & $x$ & $x$ & $x$ \\
\hline 9. & Kelola Pesan Masuk & $\boldsymbol{v}$ & $x$ & $x$ & $\mathrm{x}$ \\
\hline 10. & Lihat Laporan Pemesanan & $\boldsymbol{v}$ & $\boldsymbol{\gamma}$ & $x$ & $\mathrm{x}$ \\
\hline 11. & Lihat Laporan Data Barang & $\boldsymbol{\gamma}$ & $\boldsymbol{\gamma}$ & $\boldsymbol{\gamma}$ & $\mathrm{x}$ \\
\hline 12. & Lihat Laporan Data Pelanggan & $\boldsymbol{\gamma}$ & $x$ & $x$ & $\mathrm{x}$ \\
\hline 13. & Lihat Katalog Produk & $\boldsymbol{v}$ & $\boldsymbol{\gamma}$ & $\boldsymbol{\gamma}$ & $\boldsymbol{v}$ \\
\hline 14. & Akses Keranjang Belanja & $x$ & $x$ & $x$ & $\boldsymbol{\nu}$ \\
\hline 15. & Input Data Pemesan & $\mathrm{x}$ & $\mathrm{x}$ & $\mathrm{x}$ & $\boldsymbol{v}$ \\
\hline 16. & Checkout Pemesanan & $x$ & $x$ & $x$ & $\boldsymbol{v}$ \\
\hline 17. & Konfirmasi Pembayaran Order & $x$ & $x$ & $x$ & $\boldsymbol{v}$ \\
\hline 18. & Akses Halaman Status Order & $x$ & $x$ & $\mathrm{x}$ & $\boldsymbol{v}$ \\
\hline 19. & Konfirmasi Terima Barang & $x$ & $x$ & $x$ & $\boldsymbol{v}$ \\
\hline 20. & Kirim Pesan (Hubungi Penjual) & $\mathrm{x}$ & $\mathrm{x}$ & $\mathrm{x}$ & $\boldsymbol{\gamma}$ \\
\hline 21. & Akses Halaman Panduan & $\boldsymbol{\gamma}$ & $\boldsymbol{\gamma}$ & $\boldsymbol{\gamma}$ & $\boldsymbol{\gamma}$ \\
\hline 22. & Akses Halaman Profil kami & $\boldsymbol{V}$ & $\boldsymbol{V}$ & $\boldsymbol{v}$ & $\boldsymbol{v}$ \\
\hline
\end{tabular}

e) Kolom When $x$ Subcontractor

Kolom when menjelaskan tentang detail jadwal pelaksanaan pekerjaan coding yang dibutuhkan programmer untuk membangun sistem informasi e-commerce pada Toko Wingko \& Bandeng Presto Super Vit yang dimodelkan dalam bentuk tabel GANTT chart seperti berikut: 


\begin{tabular}{|c|l|c|c|c|c|c|c|c||}
\hline \multirow{2}{*}{ No } & \multicolumn{1}{|c|}{ Rencana Kegiatan } & \multicolumn{5}{|c|}{ Mei 2018} & \multicolumn{3}{|c|}{ Juni 2018} \\
\cline { 3 - 10 } & & 1 & 2 & 3 & 4 & 1 & 2 & 3 \\
\hline 1 & Penentuan User Level Akses Pada Sistem & & & & & & & \\
\hline 2 & Pengkodean (Coding) & & & & & & & \\
\hline 3 & Pengujian (Blackbox Testing) & & & & & & & \\
\hline
\end{tabular}

Gambar 17. Time Schedule Pelaksanaan Coding

\section{f) Kolom Why x Subcontractor}

Kolom ini berfokus pada aturan-aturan yang perlu diterapkan dalam proses pembuatan program (coding) sistem informasi e-commerce Toko Wingko \& Bandeng Presto Super Vit, yaitu:

1. Sebagian besar script PHP yang dibuat sudah terkoneksi dengan server database MySQL dan dapat melakukan query SELECT, INSERT, UPDATE, dan DELETE data.

2. Pembuatan Login dengan menggunakan fungsi session untuk mengatur proses identifikasi apakah user tersebut berhak masuk ke dalam sistem atau tidak.

3. Setiap pembuatan form input akan disertai validasi atau pemeriksaan data yang diinputkan oleh user untuk menjamin bahwa data yang disimpan memiliki format yang seragam.

\subsection{The Functioning Enterprise}

Pada baris ini sudut pandang user/pengguna merupakan tahap implementasi dari hasil perancangan sistem informasi e-commerce yang dibangun.

\section{a) Kolom What $x$ Functioning Enterprise}

Pada kolom ini berisi tentang pengisian atribut-atribut tipe data dengan menambahkan constraint primary key ke dalam masing-masing tabel entitas yang telah dibuat dan digambarkan sebelumnya pada kolom what perspektif subcontractor.

b) Kolom How x Functioning Enterprise

Dalam sel ini berisikan contoh print out hasil dari prototype website e-commerce Toko Wingko $\&$ Bandeng Presto Super Vit yang sudah dibuat dan selanjutnya akan dilakukan pengujian lack box untuk memastikan sistem telah bekerja dengan baik.

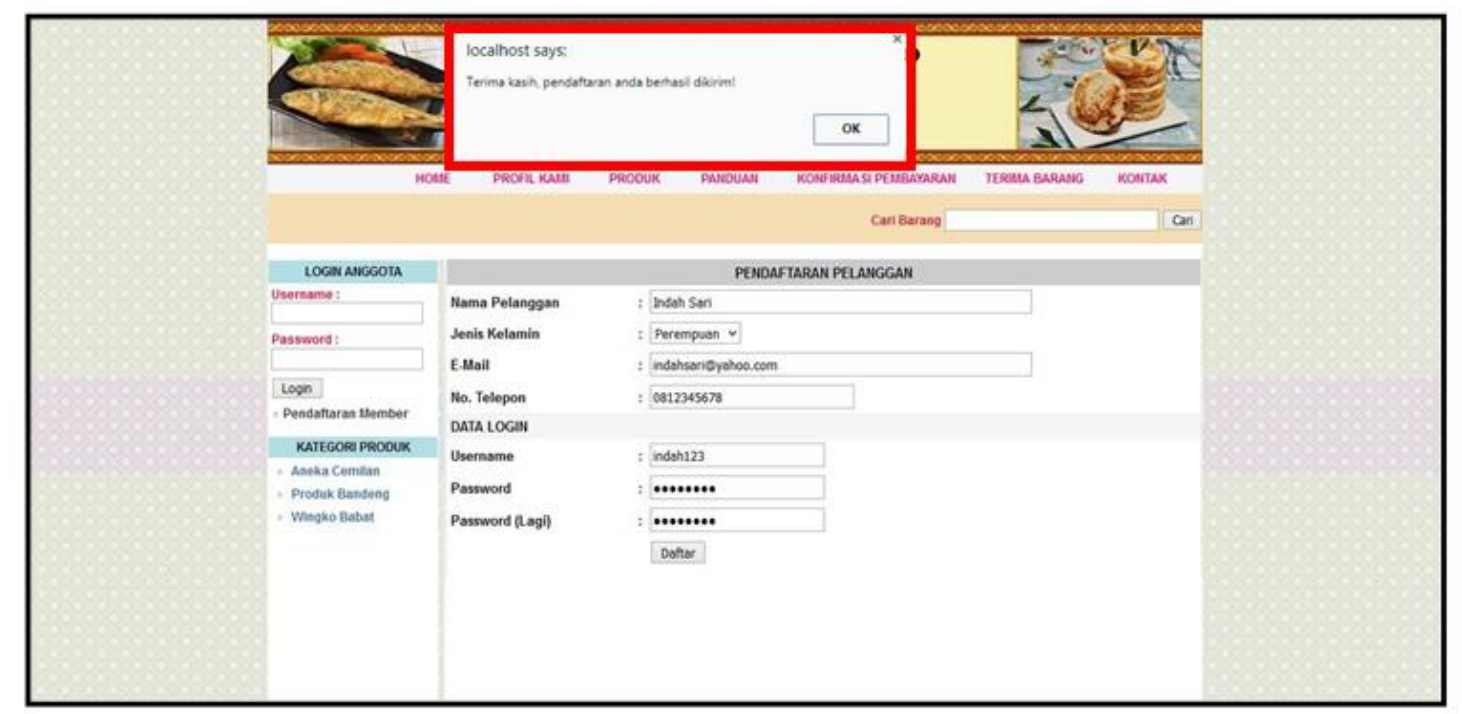

Gambar 18. Produk Berhasil Masuk Keranjang 
c) Kolom Where x Functioning Enterprise

Pada sel ini berisi konfigurasi kebutuhan hardware dan software yang dibutuhkan untuk menjalankan aplikasi sistem informasi e-commerce.

\begin{tabular}{|c|c|}
\hline Jenis Sofreare & Kebufuhan Mfinimum \\
\hline Sistem Operasi & Windows 7 \\
\hline Web Browser & Google Chrome, Mozilla Firefox \\
\hline Jeais Hordhare & Kebutuhan Mlinimum \\
\hline Processor & Intel Pentium $4(2.0 \mathrm{GH} z)$ \\
\hline RAM & $512 \mathrm{Mb}$ \\
\hline Hard Disk & $40 \mathrm{~GB}$ \\
\hline Modem / $m-f l$ & Kecepatan 5 Mops \\
\hline
\end{tabular}

Gambar 19. Spesifikasi Minimum Software dan Hardware Dari Sisi Client

d) Kolom Who x Functioning Enterprise

Kolom ini berisikan daftar nama user yang akan berinteraksi langsung dengan website $e$ commerce Toko Wingko \& Bandeng Presto Super Vit beserta hak akses/ user levelnya masingmasing dalam menggunakan sistem.

e) Kolom When x Functioning Enterprise

Dalam kolom ini dijelaskan time schedule keseluruhan proyek sistem mulai dari perancangan sistem, desain sistem, pengujian sistem sampai implementasi prototype aplikasi pada Toko Wingko \& Bandeng Presto Super Vit.

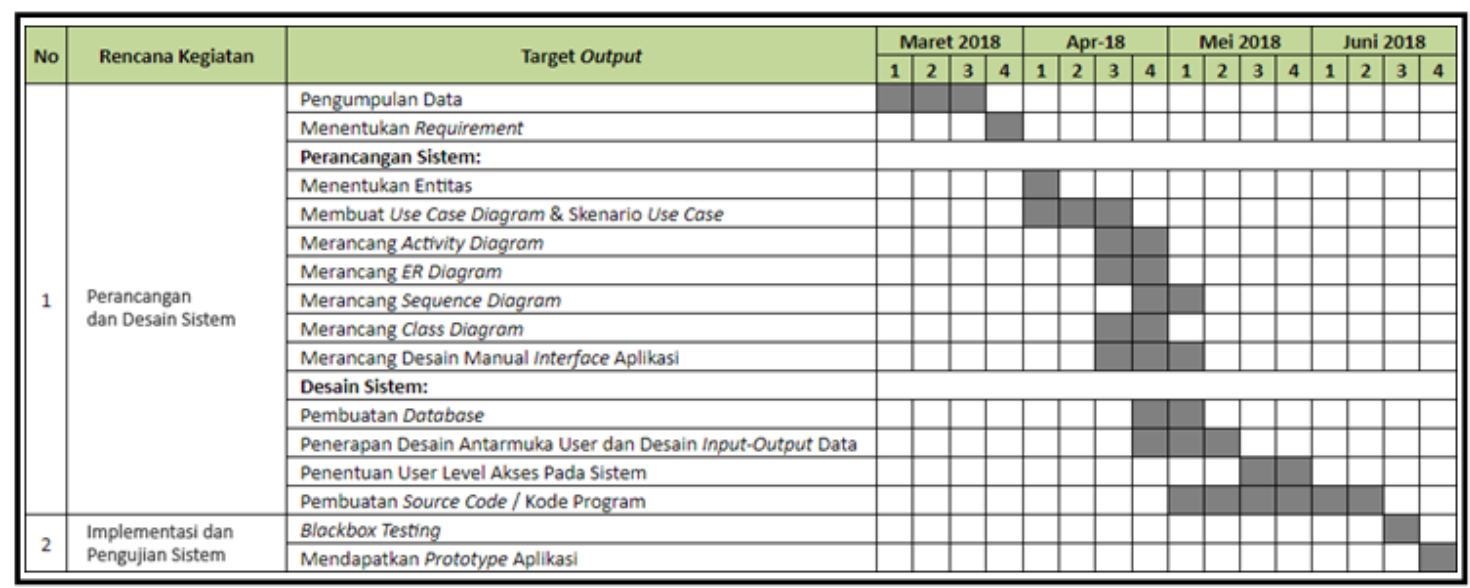

Gambar 20. Time Schedule Proses Perancangan, Desain, Pengujian dan Implementasi

\section{f) Kolom Why x Functioning Enterprise}

Kolom ini menjelaskan petunjuk tentang penggunaan modul atau fitur-fitur yang terdapat pada web sistem informasi e-commerce Toko Wingko \& Bandeng Presto Super Vit sebagai panduan bagi user yang akan menggunakan dan mengelola website tersebut. 
Tabel 4. Modul / Fitur Halaman Front End System (Customer)

\begin{tabular}{|c|c|}
\hline Model / Fitur & Aktivitas / Fungsi \\
\hline $\begin{array}{l}\text { Pendaftaran } \\
\text { Member }\end{array}$ & $\begin{array}{l}\text { Berfungsi untuk menampilkan form yang dapat digunakan untuk melakukan } \\
\text { registrasi anggota dengan mengisikan nama lengkap, alamat, no. telepon, email, } \\
\text { username, dan password }\end{array}$ \\
\hline Login & $\begin{array}{l}\text { Berfungsi untuk login ke website dengan memasukan username dan password } \\
\text { yang sudah didaftarkan sebelumnya. }\end{array}$ \\
\hline Home / Beranda & Berfungsi untuk menampilkan halaman utama website \\
\hline Kolom Search & Berfungsi untuk mencari produk yang akan dibeli. \\
\hline Profil Kami & $\begin{array}{l}\text { Berfungsi untuk menampilkan informasi profil dari Toko Wingko \& Bandeng } \\
\text { Presto Super Vit. }\end{array}$ \\
\hline $\begin{array}{l}\text { Produk dan } \\
\text { Detail Produk }\end{array}$ & Berfungsi untuk menampilkan kategori produk, gambar produk dan detail produk \\
\hline Button Beli & Berfungsi untuk menampilkan kategori produk, gambar produk dan detail produk. \\
\hline Keranjang & Berfungsi untuk menampilkan produk-produk yang sudah masuk ke dalam \\
\hline Belanja & $\begin{array}{l}\text { keranjang belanja. Fitur ini akan secara otomatis mengupdate jumlah produk yang } \\
\text { telah diisikan di dalam keranjang belanja }\end{array}$ \\
\hline Lanjutkan / & Berfungsi untuk mengeksekusi produk yang akan di order dengan menampilkan \\
\hline Checkout & konfirmasi belanja dan form checkout pemesanan yang harus dilegkapi customer \\
\hline
\end{tabular}

\section{KESIMPULAN}

Dari hasil pembahasan yang telah dilakukan oleh penulis, maka dapat ditarik kesimpulan bahwa model blueprint rancangan enterprise architecture system yang dianalisis menggunakan Zachman Framework pada Toko Wingko \& Bandeng Presto Super Vit ini menghasilkan sebuah arsitektur data, fungsi, jaringan, sumber daya manusia, waktu dan motivasi yang dilihat dari enam perspektif, yaitu planner (scope), owner (business model), designer (system model), builder (technology model), subcontractor (detailed representation) dan functioning enterprise. Model blueprint rancangan enterprise architecture system dapat diterapkan untuk merancang sistem informasi e-commerce di Toko Wingko \& Bandeng Presto Super Vit, yaitu dengan menggunakan diagram UML, seperti use case diagram, activity diagram, sequence diagram, class diagram dan entity relationship diagram. Dihasilkan sebuah prototype sistem informasi e-commerce yang dibangun berdasarkan blueprint dari enam perspektif Zachman Framework, sehingga menghasilkan serangkaian solusi yang dapat diterapkan di Toko Wingko \& Bandeng Presto Super Vit.

\section{SARAN}

Untuk penelitian lebih lanjut agar hasil lebih optimal dan tepat maka terdapat beberapa saran dengan dilakukan pengukuran dokumen perancangan hasil analisis Zachman Framework, untuk mengecek kualitas hasil dari blueprint enterprise architecture. Sistem dapat dikembangkan lagi ke dalam beberapa platform yang lebih luas seperti mobile platform, Android/IOS agar lebih memudahkan pengguna dalam melakukan transaksi mel alui smartphone dan jangkauan pemasaran menjadi lebih luas. Penggunaan metode lain seperti TOGAF ADM juga dapat digunakan untuk menganalisis pada penelitian ini.

\section{DAFTAR PUSTAKA}

[1] R. R. Sani, I. B. Fachreza dan F. E. Nilawati, "Perancangan E-commerce Pada Produk Wingko Babat Pak Moel Berbasis Web," Jounal of Information System, vol. 3, no. 2, pp. 151-160, 2018. 
[2] K. Ridlan Ahmad, "Prototipe aplikasi manajemen sparepart atm menggunakan framework zachman pada logistik asp," Bangkit Indones., vol. VIII, no. 1, pp. 9-18, 2019.

[3] V. Rosalina, "Penerapan Zachman Framework Dalam Merancang Infrastruktur Jaringan Komputer Customer Relationship Management ( Crm ) Pada Universitas," J. prosisko, vol. 2, no. 2, 2015.

[4] F. Prakosa, "Information System Strategic Plan Using Zachman Framework and Raise at XYZ Vocational High School in Jakarta," I-Statement, vol. 4, no. 2, pp. 93-99, 2018.

[5] T. A. Nugraha, M. Imrona, and E. Darwiyanto, "Pengembangan Sistem Informasi pada Perusahaan Dagang Menggunakan Zachman Framework Studi Kasus: Toko Perlengkapan Pesta Party Partner," Ind. J. Comput., vol. 4, no. August, pp. 1-8, 2019.

[6] M. A. Yaqin, F. Ade, A. Prayoga, A. N. Ihsan, and F. Pulungan, "Arsitektur Enterprise pada Permainan Hay Day Menggunakan Metode Zachman Framework," in Seminar Nasional Inovasi dan Aplikasi Teknologi di Industri 2019, 2019, pp. 50-58.

[7] M. Ayundyahrini, S. Suprapto, F. Fahma, W. Soetopo, and E. Pujiyanto, "Analisis Kebutuhan Teknis Stakeholder Pada Produk Kursi Roda Manual Menggunakan Zachman Framework," J. Ilm. Tek. Ind., vol. 18, no. 1, pp. 55-63, 2019.

[8] V. Indra and L. P. Dewi, "Enterprise Architecture Pada CV . Grande Zangrandi Dengan Metode Enterprise Architecture Planning (EAP)," no. 121.

[9] L. Ertaul and V. Rathod, "The Zachman Framework, the Owner's Perspective \&amp; Security."

[10] R. Pramudita and N. Safitri, "Integrasi Zachman Framework dan TOGAF ADM ( Architecture Development Method )," Inf. Syst. Educ. Prof., vol. 1, no. 2, pp. 157-166, 2016.

[11] D. Carr and S. Else, "State of Enterprise Architecture Survey: Results and Findings," 2018.

[12] S. Kotusev, "Fake and Real Tools for Enterprise Architecture : The Zachman Framework and Business Capability Model The Zachman Framework : A Fake Tool," no. August, pp. $1-14,2019$.

[13] S. Larno, "a Method Framework of Integrating Information Security Into the Enterprise Architecture," 2019.

[14] O. Noran, "An analysis of the Zachman framework for enterprise architecture from the GERAM perspective,” Annu. Rev. Control, vol. 27 II, no. December 2003, pp. 163-183, 2003.

[15] J. Zachman, "Zachman, J.: A Framework for Information Systems Architecture. IBM Systems Journal 26, 276-292," IBM Syst. J., vol. 38, no. September, pp. 276-292, 1987.

[16] I. Gamayanto and H. Christian, "The Development of Innovative CRM E-Commerce: The Case of Blibli.Com," Binus Bus. Rev., vol. 9, no. 1, p. 29, 2018. 